Mineral Resources of the Eagle Mountain Wilderness Study Area, Pitkin County, Colorado
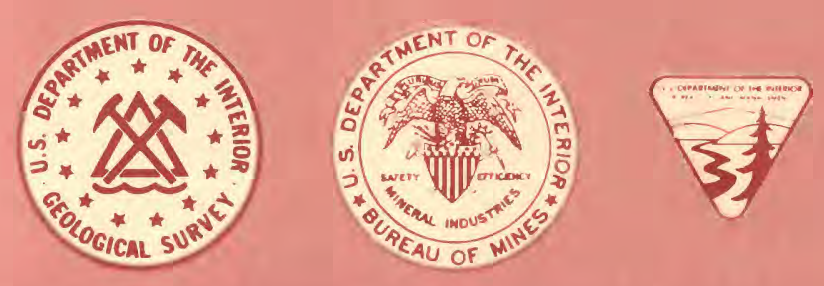

U.S. GEOLOGICAL SURVEY BULLETIN 1717-B

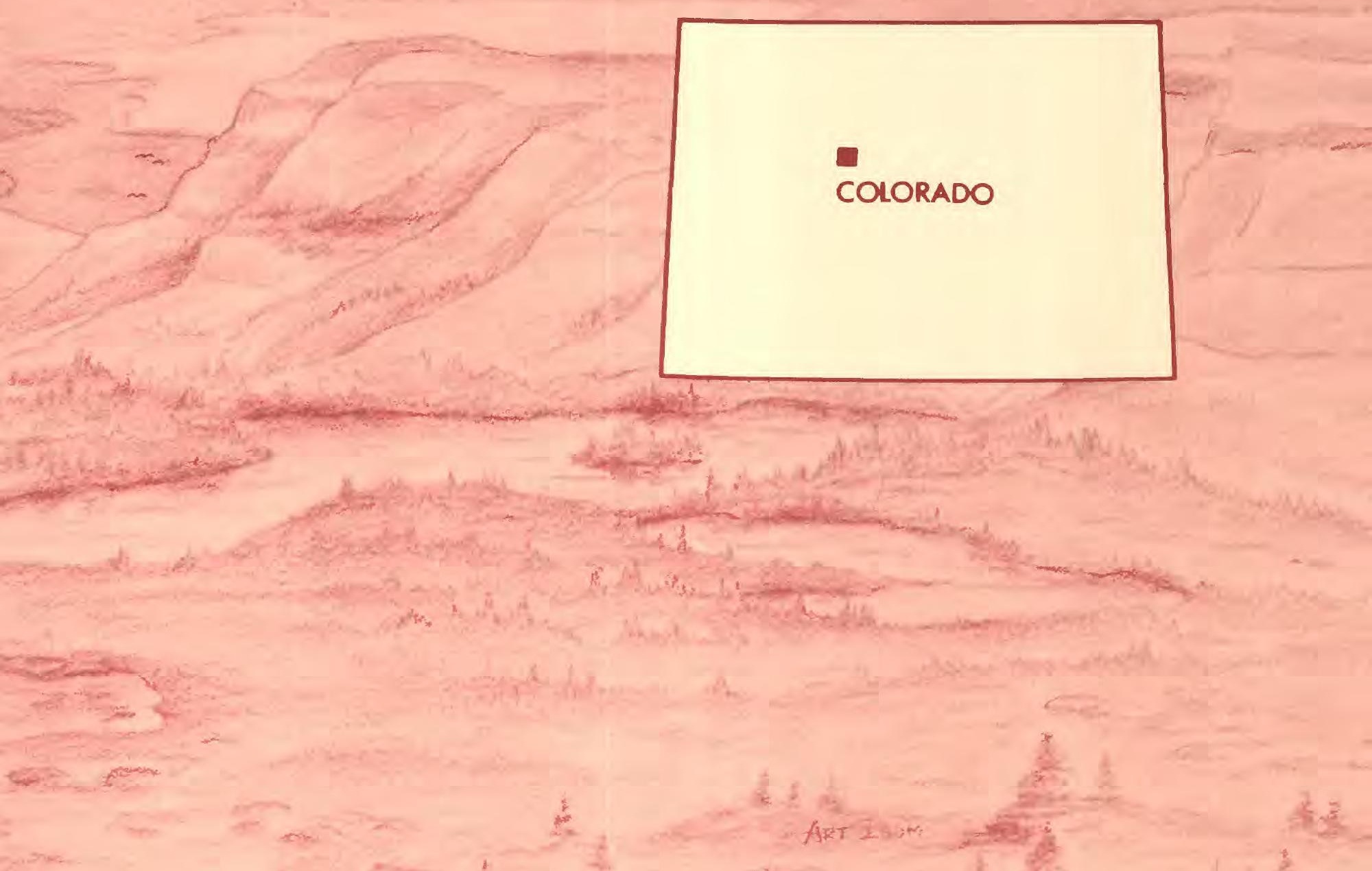




\section{DEFINITION OF LEVELS OF MINERAL RESOURCE POTENTIAL AND CERTAINTY OF ASSESSMENT}

\section{Definitions of Mineral Resource Potential}

LOW mineral resource potential is assigned to areas where geologic, geochemical, and geophysical characteristics define a geologic environment in which the existence of resources is unlikely. This broad category embraces areas with dispersed but insignificantly mineralized rock as well as areas with few or no indications of having been mineralized.

MODERATE mineral resource potential is assigned to areas where geologic, geochemical, and geophysical characteristics indicate a geologic environment favorable for resource occurrence, where interpretations of data indicate a reasonable likelihood of resource accumulation, and (or) where an application of mineral-deposit models indicates favorable ground for the specified type(s) of deposits.

HIGH mineral resource potential is assigned to areas where geologic, geochemical, and geophysical characteristics indicate a geologic environment favorable for resource occurrence, where interpretations of data indicate a high degree of likelihood for resource accumulation, where data support mineral-deposit models indicating presence of resources, and where evidence indicates that mineral concentration has taken place. Assignment of high resource potential to an area requires some positive knowledge that mineral-forming processes have been active in at least part of the area.

UNKNOWN mineral resource potential is assigned to areas where information is inadequate to assign low. moderate, or high levels of resource potential.

NO mineral resource potential is a category reserved for a specific type of resource in a well-defined area

\section{Levels of Certainty}

\begin{tabular}{|c|c|c|c|}
\hline U/A & $\begin{array}{l}\text { H/B } \\
\text { HIGH POTENTIAL }\end{array}$ & $\begin{array}{l}\text { H/C } \\
\text { HIGH POTENTIAL }\end{array}$ & $\begin{array}{l}\text { H/D } \\
\text { HIGH POTENTIAL }\end{array}$ \\
\hline \multirow{3}{*}{$\begin{array}{l}\text { UNKNOWN } \\
\text { POTENTIAL }\end{array}$} & $\begin{array}{l}\text { M/B } \\
\text { MODERATE POTENTIAL }\end{array}$ & $\begin{array}{l}\text { M/C } \\
\text { MODERATE POTENTIAL }\end{array}$ & $\begin{array}{l}\text { M/D } \\
\text { MODERATE POTENTIAL }\end{array}$ \\
\hline & \multirow{2}{*}{$\begin{array}{l}\text { LOW } \\
\text { POTENTIAL }\end{array}$} & \multirow{2}{*}{$\begin{array}{l}\text { LOW } \\
\text { POTENTIAL }\end{array}$} & $\begin{array}{l}\text { L/D } \\
\text { LOW POTENTIAL }\end{array}$ \\
\hline & & & $\begin{array}{l}\text { N/D } \\
\text { NO POTENTIAL }\end{array}$ \\
\hline A & B & C & D \\
\hline
\end{tabular}

\footnotetext{
A. Available information is not adequate for determination of the level of mineral resource potential

B. Available information suggests the level of mineral resource potential.

C. Available information gives a good indication of the level of mineral resource potential.

D. Available information clearly defines the level of mineral resource potential.
}

\section{Abstracted with minor modifications from:}

Taylor, R. B., and Steven, T. A., 1983, Definition of mineral resource potential: Economic Geology, v. 78 , no. 6. p. $1268-1270$.

Taylor, R. B., Stoneman. R. J., and Marsh. S. P., 1984. An assessment of the mineral resource potential of the San Isabel National Forest. south-central Colorado: U.S. Geological Survey Bulletin 1638, p. $40-42$.

Goudarzi. G H. compiler, 1984, Guide to preparation of mineral survey reports on public lands: U.S. Geological Survey Open-File Report 84-0787, p. 7.8 
Chapter B

MINERAL RESOURCES OF WILDERNESS STUDY AREAS-

NORTH-CENTRAL COLORADO

\section{Mineral Resources of the Eagle Mountain \\ Wilderness Study Area, Pitkin County, Colorado}

By Sandra J. Soulliere and Mark A. Arnold,

U.S. Geological Survey, and

Steven E. Kluender and Jeanne E. Zelten,

U.S. Bureau of Mines 


\section{DEPARTMENT OF THE INTERIOR DONALD PAUL HODEL, Secretary}

\section{U.S.GEOLOGICAL SURVEY}

Dallas L. Peck, Director

\section{Library of Congress Cataloging in Publication Data}

Mineral resources of the Eagle Mountain Wilderness Study area, Pitkin County, Colorado

(U.S. Geological Survey bulletin ; 1717-B)

Bibliography $\mathbf{p}$.

Supt. of Docs. No.: | 19.3:1717-B

1. Mines and mineral resources-Colorado-Eagle Mountain Wilderness. 2. Geology-Colorado-Eagle Mountain Wilderness. 3. Eagle Mountain Wilderness (Colo.) I. Soulliere, Sandra J. II. Series. QE75.B9 no. 1717-B $557.3 \mathrm{~s}$ [553'.9788' 43$]$

$86-600004$ [TN24.C6]

UNITED STATES GOVERNMENT PRINTING OFFICE: 1986

For sale by the Branch of Distribution

U.S. Geological Survey

604 South Pickett Street

Alexandria, VA 22304 


\section{STUDIES RELATED TO WILDERNESS}

\section{Bureau of Land Management Wilderness Study Areas}

The Federal Land Policy and Management Act (Public Law 94-579, October 21, 1976) requires the U.S. Geological Survey and the U.S. Bureau of Mines to conduct mineral surveys on certain areas to determine the mineral values, if any, that may be present. Results must be made available to the public and be submitted to the President and the Congress. This report presents the results of a mineral survey of the Eagle Mountain (CO-070-392) Wilderness Study Area, Pitkin County, Colorado. 



\section{CONTENTS}

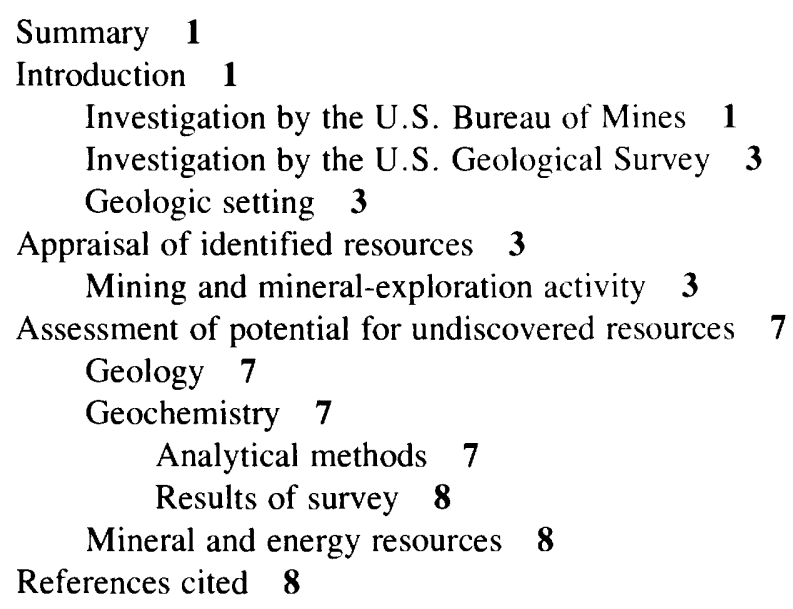

\section{FIGURES}

1. Map showing mineral resource potential of the Eagle Mountain Wilderness Study Area 2

2. Geologic map and cross section of the Eagle Mountain Wilderness Study Area 4

3. Mine and prospect map of the Eagle Mountain Wilderness Study Area 6 


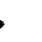




\title{
Mineral Resources of the Eagle Mountain Wilderness Study Area, Pitkin County, Colorado
}

\author{
By Sandra J. Soulliere and Mark A. Arnold \\ U.S. Geological Survey and \\ Steven E. Kluender and Jeanne E. Zelten \\ U.S. Bureau of Mines
}

\section{SUMMARY}

In 1983 and 1984 the U.S. Bureau of Mines and the U.S. Geological Survey conducted investigations to appraise the identified mineral resources and assess the mineral resource potential of the Eagle Mountain (CO070-392) Wilderness Study Area. These investigations revealed no identified mineral resources and low mineral resource potential for undiscovered resources including base and precious metals, oil, gas, and uranium (fig. 1).

The Eagle Mountain Wilderness Study Area is about $10 \mathrm{mi}$ (miles) west of Aspen, in Pitkin County, Colo., (fig. 1). Steep, mountainous topography is typical of the 330-acre study area, which adjoins the Maroon Bells-Snowmass Wilderness in the White River National Forest. At least $5,200 \mathrm{ft}$ of Pennsylvanian to Cretaceous age sedimentary rocks are exposed in one-half of the study area (fig. 2); Quaternary glacial deposits and colluvium cover one-third. The Snowmass Creek fault zone, a series of arcuate faults, cuts the southern edge of the study area.

No minerals have been produced and no surface evidence exists for metallic-mineral or energy resources in the Eagle Mountain Wilderness Study Area. Minor but unknown amounts of copper and silver have been produced from mines within $0.25 \mathrm{mi}$ of it. No mines, pros- pects, mineralized areas, patented mining claims, or mineral leases were identified in the study area. Sand, gravel, and industrial rock resources are in the study area, but sufficient quantities are available elsewhere to satisfy current local needs.

Copper, lead, silver, zinc, uranium, and vanadium minerals may occur below surface in favorable host rocks, most likely the Dakota Sandstone and Mancos Shale, or along faults which transect the study area. However, geological and geochemical evidence suggest

a low potential for these metals. No surface evidence of uranium mineralization was noted during the field investigation, and no uranium was detected in the geochemical samples. Although the Morrison Formation is a favorable host rock for uranium, the potential for the presence of this resource is low. Oil and gas potential is low. Temperatures were too high for the preservation of oil in favorable reservoir rocks, and the structural setting is unfavorable for gas.

\section{INTRODUCTION}

The Eagle Mountain (CO-070-392) Wilderness Study Area in Pitkin County, Colorado, is about $10 \mathrm{mi}$ west of Aspen and comprises approximately 330 acres (fig. 1). The western boundary of the study area is the Maroon Bells-Snowmass Wilderness in the White River National Forest. The area is accessible from a county road which forms parts of the southern boundary.

Steep, mountainous topography is typical of the study area, in which elevations range from $8,280 \mathrm{ft}$ (feet) near Snowmass Creek to $9,937 \mathrm{ft}$ at the summit of Eagle Mountain. Several intermittent streams drain the study area and flow into Snowmass Creek, a tributary to the Roaring Fork river.

\section{Investigation by the U.S. Bureau of Mines}

In September 1983, the U.S. Bureau of Mines (USBM) conducted a mineral investigation of the Eagle Mountain Wilderness Study Area (Kluender and Zelten, 1985). Prior to the field investigation, USBM geologists reviewed published and unpublished information, inter- 


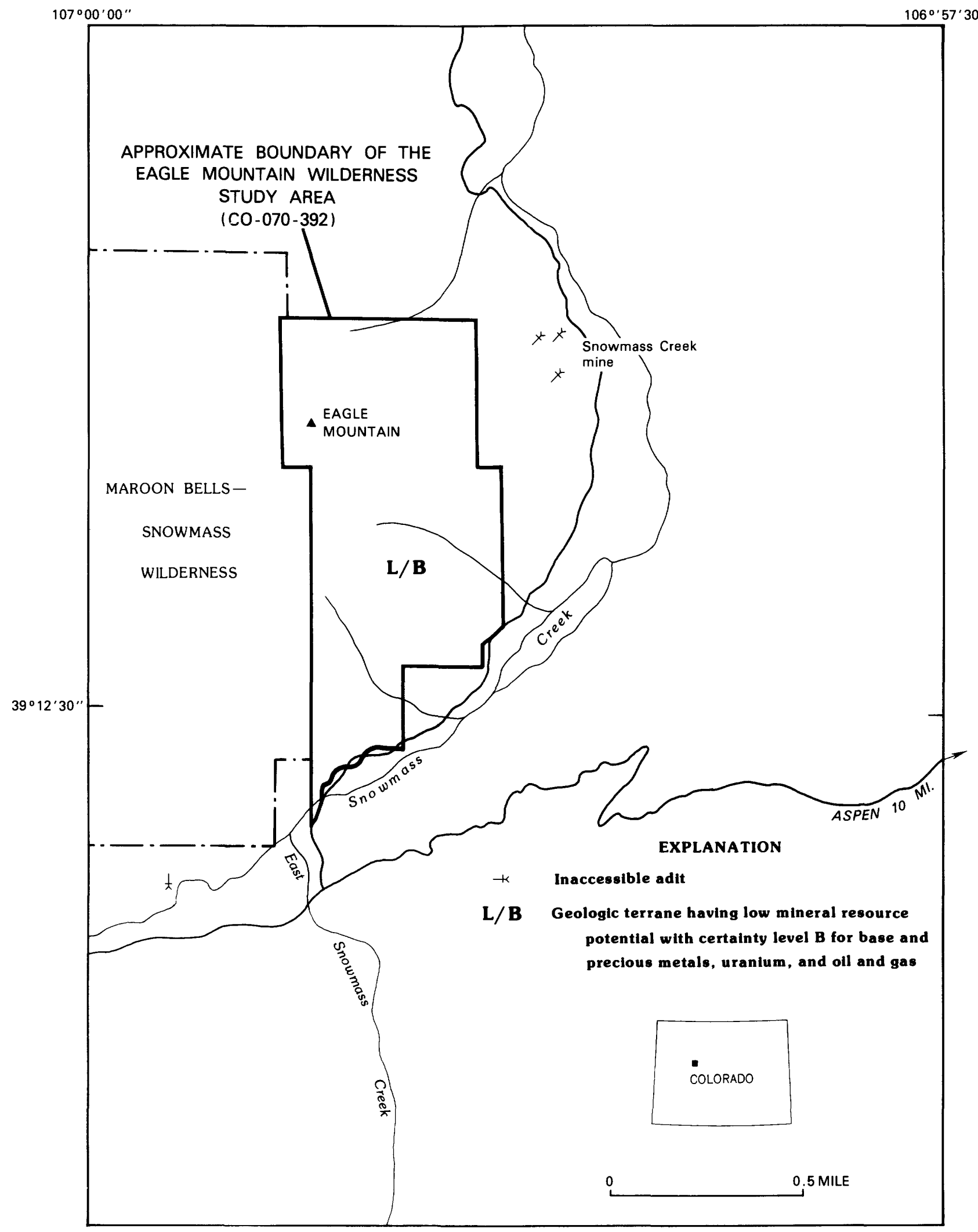

Figure 1. Map showing mineral resource potential of the Eagle Mountain Wilderness Study Area, Pitkin County, Colorado. 
viewed local residents and personnel from the USBM and U.S. Bureau of Land Management (BLM) regarding minerals in the area, and examined BLM and county records for locations of patented and unpatented mining claims and mineral leases.

\section{Investigation by the U.S. Geological Survey}

In June 1984, the U.S. Geological Survey (USGS) conducted an investigation to assess the potential for undiscovered mineral resources of the Eagle Mountain Wilderness Study Area. This investigation consisted of a review of previous geologic mapping, collection of streamsediment and rock samples for geochemical analyses, and a search for mines, prospects, and mineralized areas. Complete USGS analytical data are available for public inspection at the U.S. Geological Survey, MS 905, Building 25, Denver Federal Center, Denver CO 80225. The assessment of undiscovered mineral resources is based on the above work, the geologic map of the Highland Peak quadrangle (Bryant, 1972), and the USGS-USBM study of the Maroon Bells-Snowmass Wilderness (Freeman and Weisner, 1984). Bryant (1979) also was a valuable source of information about the mineralization in the area and the geology of the Snowmass Creek mine, just outside the study area. Mineral resource potential was classified according to the system of Goudarzi (1984).

\section{Geologic Setting}

The Eagle Mountain Wilderness Study Area is in the Middle Rocky Mountains physiographic province and lies within the Eagle basin between the White River uplift and the Sawatch uplift. The area is just north of the Colorado mineral belt and northeast of the Uncompahgre uplift. Regional geology of the middle Rocky Mountains consists of a number of Laramide uplifts modified by Tertiary plutons and faults (Bryant, 1979).

Sedimentary rocks of Pennsylvanian to Cretaceous age are exposed in the proposed wilderness (fig. 2). The Mancos Shale (unit Km, fig. 2), Dakota Sandstone and Burro Canyon Formation (unit $\mathrm{Kdb}$ ), and the Morrison Formation (unit $\mathrm{Jm}$ ) crop out in the northern part of the study area; the Entrada Sandstone (unit Je), the Chinle Formation (unit $\mathrm{kc}$ ), the State Bridge Formation (unit $\mathrm{K} P$ s), and the Maroon Formation (unit PPm) crop out in the southern half. Quaternary colluvium (unit Qc) and glacial-moraine deposits (unit Qm) cover parts of the study area. The Snowmass Creek fault zone, transecting the southeastern boundary of the study area, consists of a series of arcuate faults. According to Bryant (1979), this fault zone was associated with Tertiary intrusive activity. One prominent north-trending fault, with both left- lateral and vertical offsets, cuts the sedimentary rocks along the western boundary and may join the Snowmass Creek fault zone near the southern part of the study area.

\section{APPRAISAL OF IDENTIFIED RESOURCES}

\section{By Steven E. Kluender and Jeanne E. Zelten, U.S. Bureau of Mines}

\section{Mining and mineral-exploration activity}

There has been no mineral production and there is no surface evidence of metallic-mineral or energy resources in the Eagle Mountain Wilderness Study Area, which is in the Snowmass mining district. A small unknown amount of copper-silver ore of unknown grade was shipped from the Snowmass Creek mine, $0.25 \mathrm{mi}$ northeast of the study-area boundary (fig. 3) (Bryant, 1979). No mines, prospects, mineralized areas, patented mining claims, or mineral leases are in the study area. As of September 1984, BLM files showed 10 unpatented mining claims in or within $1 \mathrm{mi}$ of the study area. Several patented mining claims are within $1 \mathrm{mi}$ southwest of the area (fig. 3). An oil and gas lease (C36477) is $0.5 \mathrm{mi}$ east of the study area. Three test holes drilled for oil and gas about 4 mi northeast of the study area were dry.

Sulfide minerals were previously identified at three caved workings along the Snowmass Creek fault zone in the Cretaceous Dakota Sandstone, $0.25 \mathrm{mi}$ to the northeast (fig. 3). Bryant (1979) visited the workings before they were caved, and the following description of mineral occurrences at these and other workings in the region was taken from his report.

At the Snowmass Creek mine, copper and iron sulfides are associated with carbonaceous material in the Dakota Sandstone. Copper and silver, with associated molybdenum and zinc, were detected in samples taken by Bryant. He suggested a genetic relationship between the faulting and the sulfide deposits in the carbonaceous material in the Dakota. If this relationship is valid, additional copper and silver mineralized rock may be present along the northwestern boundary, about $0.75 \mathrm{mi}$ west of the Snowmass Creek mine, where another fault cuts the Dakota. If the mineralization was controlled by the presence of carbonaceous material which created a reducing environment and caused precipitation of sulfide minerals from ground water, then mineralization could have been more widespread in the Dakota. No surface evidence of mineralization along this second fault or in the Dakota was noted during the investigation. The mineral occurrence at the Snowmass Creek mine is small; there is no surface indication of a deposit of large tonnage.

Several workings on private land southwest of the study area (fig. 3) are also in the Dakota. Samples taken 


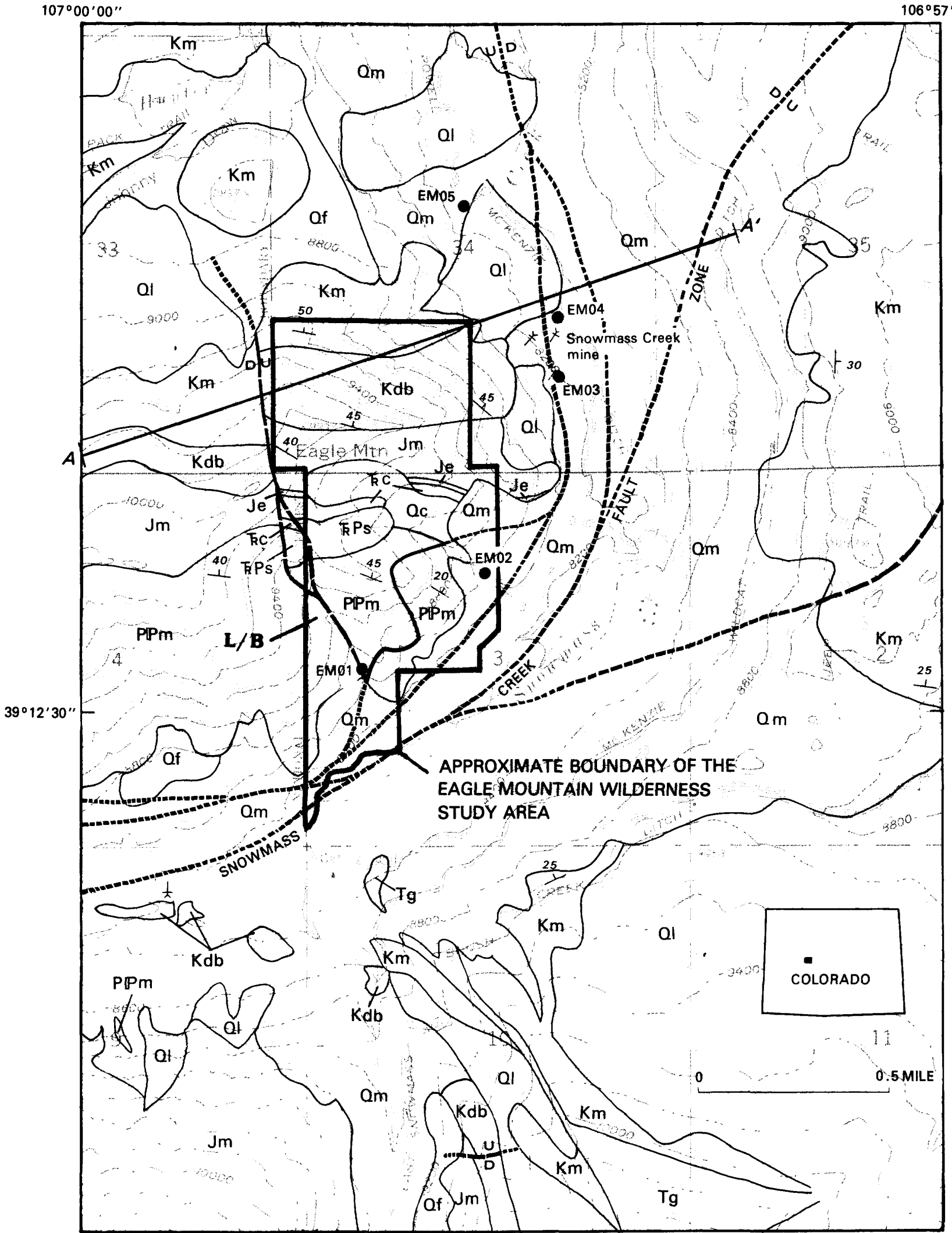

Figure 2. Geologic map and cross section of the Eagle Mountain Wilderness Study Area, Colorado. Geology modified from Bryant (1972). Base from U.S. Geological Survey Highland Peak, Colo., 1960, 1:24,000. 
EXPLANATION

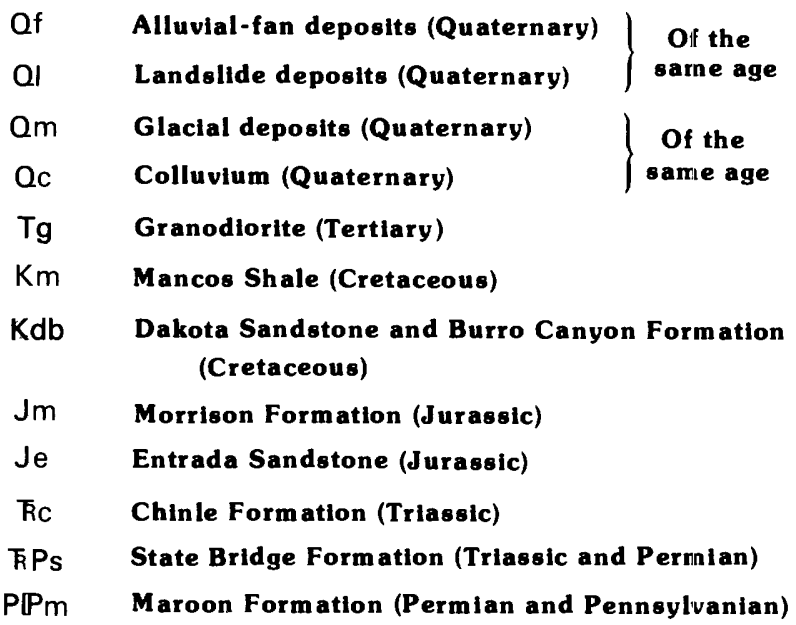

by Bryant at these workings contained lesser amounts of copper, molybdenum, and silver than those taken at the Snowmass Creek mine. These workings have no record of production. Samples taken by Bryant at other areas along the Snowmass Creek fault zone did not contain evidence of mineralization.

The Mississippian Leadville Limestone, which may underlie the area, has been mined for base and precious metals in central Colorado. If the Leadville is present beneath the study area, and if Bryant's theories of hydrothermal mineralization are correct, then there could be replacement deposits in the Leadville below the surface.

Most of the formations present in the study area were described by Bass and Northrop (1963) as "prospectively valuable as reservoirs for oil and gas" for an area $15 \mathrm{mi}$ to the north. The study area was designated by Spencer (1983) as having unknown potential because of insufficient subsurface data. Three test holes drilled for oil and gas about $4 \mathrm{mi}$ northeast of the area were dry.

The Jurassic Morrison Formation, exposed in the northern part of the study area, has been the source of about 85 percent of the uranium mined in Colorado, mostly in the Colorado Plateau physiographic province (U.S. Geological Survey, 1968). The Morrison has been prospected for uranium in the region surrounding the study area, but no uranium discovery has been reported. No surface evidence of uranium mineralization was noted during the investigation.

Sand, gravel, and industrial rock resources are present. Glacial deposits and colluvium cover almost one-third

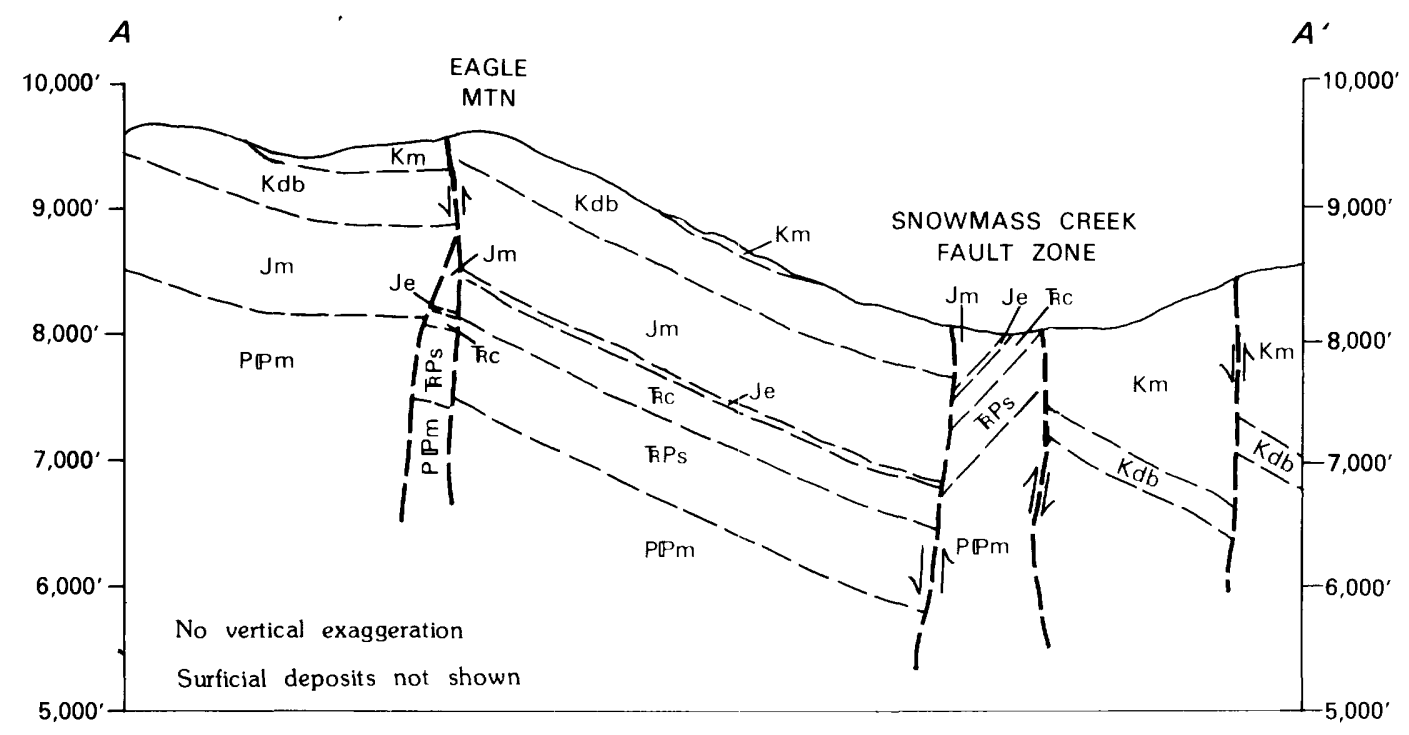

Figure 2. Continued. 


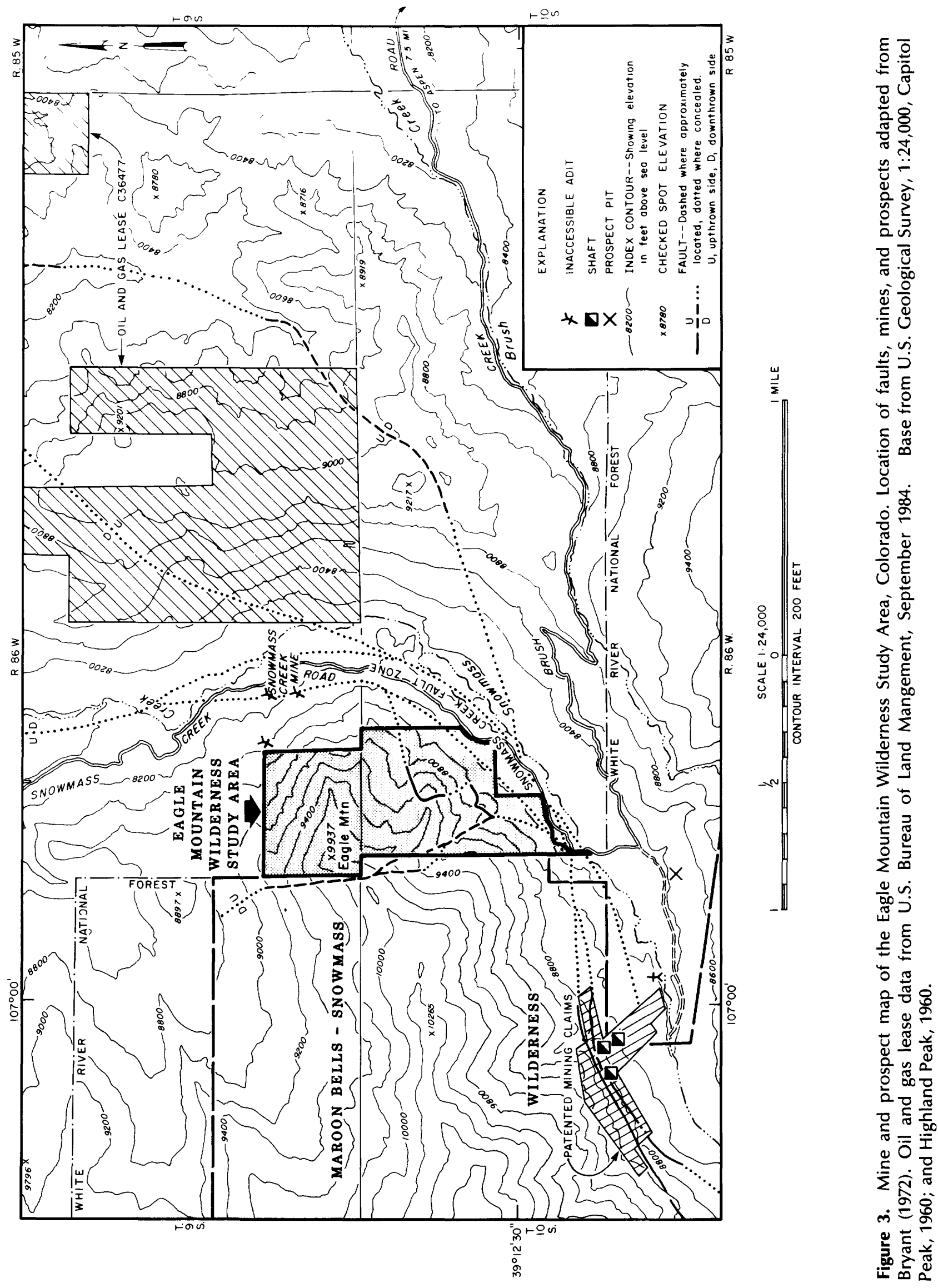


of the study area, and sandstone crops out over almost one-half. Sufficient quantities of sand and gravel are available outside the study area to satisfy current local needs.

\section{ASSESSMENT OF POTENTIAL FOR UNDISCOVERED RESOURCES}

\section{By Sandra J. Soulliere and Mark A. Arnold, U.S. Geological Survey}

\section{Geology}

Rock units in the study area were described in detail by Bryant (1972). The Maroon Formation (Pennsylvanian and Permian) is composed of grayish-red, reddish-brown, and pale-red interbedded sandstone, siltstone, mudstone, and conglomerate. These beds are generally calcareous and micaceous. A well-sorted, crossbedded, fine-grained quartz sandstone occurs locally as a large lenticular layer at the base of the formation. The Maroon Formation is unconformable with the overlying State Bridge Formation (Permian and Triassic), which consists of pale- to darkreddish-brown calcareous and micaceous siltstone, sandstone, and conglomerate. These sedimentary rocks are characterized by oscillatory ripple marks, crossbedding, and spherical quartz grains.

The Triassic Chinle Formation unconformably overlies the State Bridge Formation and consists of brick-red to very dark red calcareous siltstone and minor beds of red to very light gray silty limestone and conglomerate composed of angular fragments of limestone. The Jurassic Entrada Sandstone unconformably overlies the Chinle Formation and consists of salmon-red to pink, crossbedded, medium- to coarse-grained subrounded sandstone. The Morrison Formation (Jurassic) is conformable with the underlying Entrada Sandstone and consists of grayish-red and greenish-gray siltstone and claystone grading downward into calcareous sandstone and siltstone. Yellowishgray silty limestone and calcareous sandstone beds at the base constitute less than one-fourth of the thickness of the formation.

The Cretaceous Burro Canyon Formation conformably overlies the Morrison Formation. The Burro Canyon consists of light-gray to white quartz sandstone with interbeds of greenish-gray claystone, silty shale, and sandy siltstone. The Dakota Sandstone was mapped together with the Burro Canyon. It consists of dark-gray siltstone and shale interbedded with medium-gray sandstone. The sandstone locally contains plant fragments. The Cretaceous Mancos Shale conformably overlies the Dakota. It consists of dark-gray silty shale with thin beds of siltstone and fine-grained sandstone. The Fort Hays Limestone Member of the Mancos Shale consists of dark-gray limestone in $1-2 \mathrm{ft}$ thick beds.
A Tertiary hornblende granodiorite occurs as a thin sill and as dikes about $0.5 \mathrm{mi}$ south of the study area. It is light greenish gray, fine grained, and generally altered. The granodiorite may be present beneath the study area, but no surface evidence was found. Quaternary alluvium and glacial deposits cover the area around Snowmass Creek.

The Snowmass Creek fault zone, a series of arcuate faults, cuts the southeastern edge of the study area. According to Bryant (1979), this fault zone had post-Dakota movement during the emplacement of a granodiorite pluton. One prominent north-trending fault cuts the sedimentary rocks along the western boundary of the study area and may join the Snowmass Creek fault zone at the southern end.

\section{Geochemistry}

\section{Analytical Methods}

During an investigation of the Maroon Bells-Snowmass Wilderness, Freeman and Weisner (1984) sampled outcrops and stream sediments along the Snowmass Creek fault zone and found anomalous amounts of copper, silver, lead, zinc, molybdenum, cobalt, and gold. Because of the proximity of the Snowmass Creek fault zone to the Eagle Mountain Wilderness Study Area, these elements were of primary interest in our geochemical survey. Stream-sediment samples were collected from four sites (fig. 2). Three stream-sediment samples (EMO1, EMO2, EMO5) were collected from intermittent streams which drain the study area. An additional sample (EMO4) was collected of sediment that was deposited in drainage from one of the adits of the Snowmass Creek mine; the mine is just outside the study area. Two types of samples were collected at each of these sites. A panned-concentrate sample was prepared for analysis for heavier metallic elements such as copper, lead, zinc, silver, and gold, and a fine-fraction sample of mud was collected to analyze for metals such as molybdenum, uranium, and arsenic, which typically adhere to clay minerals.

Each panned concentrate represents a composite of three to five grab samples of coarse stream sediment which was sieved in the field through a 10-mesh (0.039in.) stainless-steel screen. The sediment was panned until only about 50 percent quartz and feldspar remained in the pan. In the laboratory, this material was dried, sieved to minus-35 mesh (0.0165 in.), processed through bromoform separation (specific gravity greater than 2.85 ) and magnetic separation (1.0 amp, side slope of $10^{\circ}$ and forward slope of $15^{\circ}$ ) to obtain nonmagnetic heavy-mineral concentrates for analyses. The nonmagnetic heavymineral-concentrate fraction was split, then ground in a mortar and pestle and analyzed semiquantitatively for 31 elements by the six-step, direct-current arc, optical-emis- 
sion spectrographic method (Grimes and Marranzino, 1968).

A fine-fraction sample, about 25 ounces of clay and mud, also was collected at each sample site. In the laboratory, the fine-fraction samples were ground with a mortar and pestle to release clay-cementing aggregates and were then sieved to minus-100 mesh (0.0059 in.). The procedure for sample preparation and analysis by inductively coupled plasma atomic-emission spectroscopy (ICP) followed the techniques of Taggart and others (1981). Each sample was analyzed for 44 elements.

Two composite mineralized rock samples (EMO3A and B) were taken from the Snowmass Creek mine dump just outside the study area. In the laboratory, the rock samples were crushed and pulverized to less than 100 mesh ( $0.0059 \mathrm{in}$.) and were analyzed by semiquantitative emission spectroscopy similar to the method used for heavy-mineral concentrates as discussed above.

\section{Results of Survey}

The heavy-mineral concentrate and stream-sediment samples contained no anomalous concentrations of precious or base metals. One sample (EMO4), taken just outside the study area, showed a higher amount of copper (190 ppm or parts per million) than other stream-sediment samples from the area (average $19 \mathrm{ppm}$ ). Uranium was not detected in any of the panned-concentrate samples.

Rocks containing visible metallic minerals, scattered about the dump at the caved Snowmass Creek mine, were sampled and analyzed. Visual examination of these samples revealed pyrite, chalcopyrite, bornite, and copper oxide minerals (malachite, azurite) in the Dakota Sandstone. The samples were also rich in plant debris. Semiquantitative spectrographic analyses of rock sample EMO3A showed greater than 2 percent copper, 1,500 ppm silver, $200 \mathrm{ppm}$ molybdenum, 1,340 ppm zinc, and $100 \mathrm{ppm}$ lead. Sample EMO3B showed greater than 2 percent copper, $200 \mathrm{ppm}$ silver, $30 \mathrm{ppm}$ molybdenum, $612 \mathrm{ppm}$ zinc, and $15 \mathrm{ppm}$ lead. These amounts reflect the high grade of the selected samples.

\section{Mineral and Energy Resources}

The mineral resource potential for the Eagle Mountain Wilderness Study Area is low for all mineral commodities (fig. 1). Available information indicates the geologic environment and suggests the low level of mineral resource potential; the certainty level is B (see inside front cover for definitions of certainty levels). Copper, lead, silver, and zinc minerals of the type found at the Snowmass Creek mine may be present in favorable host rocks or along faults which transect the study area. No metallic mineral resources were identified at the surface in the study area, and the geochemical samples taken during this investigation contained no anomalous concentrations of base or precious metals.

At the Snowmass Creek mine, copper and iron sulfide minerals replace plant debris in the Dakota Sandstone. Similar mineralized rock has not been found elsewhere in the region (Bryant, 1979). Bryant (1979) suggested that low-temperature hydrothermal fluids were responsible for the mineralization at the Snowmass Creek mine. He stated that the mineralization appeared to be controlled by the carbonaceous beds in the Dakota Sandstone and by proximity to the Snowmass Creek fault zone. If the mineralization in the study area was fault controlled, then copper, lead, silver, and zinc minerals may be present below the surface along the western boundary of the study area where the Dakota Sandstone and Mancos Shale are cut by a north-trending fault (fig. 2).

The mineralization at the Snowmass Creek mine may have been controlled by carbonaceous beds, regardless of proximity to the faults. Copper and other metals are precipitated when ground water passes through carbonaceous beds (reducing facies) in any of the sedimentary rocks. If this occurred in the area, copper, silver, lead, zinc, and associated uranium and vanadium may be present in the unexposed carbonaceous beds of the Dakota Sandstone and Mancos Shale. However, no base metals, uranium, or vanadium have been reported in the region from carbonaceous beds in the Dakota or Mancos, and none of the metals were detected by our geochemical sampling.

The Eagle Mountain Wilderness Study Area has a low mineral resource potential for uranium; the certainty level is B. No uranium minerals were identified during the field investigation, and geochemical analyses revealed no anomalous concentrations of uranium.

The mineral resource potential for oil and gas in the study area is low, with certainty level B; no producing oil fields are nearby. According to Bass and Northrop (1963), some of the formations present may be favorable reservoir rocks for oil and gas. These formations include the Leadville, Belden, Maroon, Entrada, Morrison, and Dakota. Geothermal information (Freeman and Weisner, 1984) indicated that temperatures were too high for preservation of oil in these formations. The structural setting is unfavorable for gas.

\section{REFERENCES CITED}

Bass, N. W., and Northrop, S. A., 1963, Geology of Glenwood Springs quadrangle and vicinity, northwestern Colorado: U.S. Geological Survey Bulletin 1142-J, 74 p.

Bryant, Bruce, 1972, Geologic map of the Highland Peak quadrangle, Pitkin County, Colorado: U.S. Geological Survey Geologic Quadrangle Map GQ-932, scale 1:24,000. 
1979 [1980], Geology of the Aspen 15-minute quadrangle, Pitkin and Gunnison Counties, Colorado: U.S Geological Survey Professional Paper 1073, 146 p.

Freeman, V. L., and Weisner, R. C., 1984, Maroon BellsSnowmass Wilderness and Additions, Colorado, in Marsh, S. P., Kropschot, S. J., and Dickinson, R. G., eds., Wilderness mineral potential, assessment of mineral-resource potential in U.S. Forest Service lands studied 1964-1984: U.S. Geological Survey Professional Paper 1300, v. 1, p. 458-461.

Goudarzi, G. H., compiler, 1984, Guide to preparation of mineral survey reports on public lands: U.S. Geological Survey Open-File Report 84-787, 42 p.

Grimes, D. J., and Marranzino, A. P., 1968, Direct-current arc and alternating-current spark emission spectrographic field methods for the semiquantitative analysis of geologic materials: U.S. Geological Survey Circular 591, 6 p.
Kluender, S. E., and Zelten, J. E., 1985, Mineral investigation of the Eagle Mountain Wilderness Study Area, Pitkin County, Colorado: U.S. Bureau of Mines Open File Report MLA 7-85, $11 \mathrm{p}$.

Spencer, C. W., 1983, Petroleum potential of wilderness lands, Colorado, in Miller, B. M., ed., Petroleum potential of wilderness lands in the western United States: U.S. Geological Survey Circular 902-E, 8 p.

Taggart, J. E., Jr., Lichte, F. E., and Wahlberg, J. S., 1981, Methods of analysis of samples using X-ray fluorescence and induction-coupled plasma spectroscopy, in Lipman, P. W., and Mullineaux, D. R., eds., The 1980 eruptions of Mount St. Helens, Washington: U.S. Geological Survey Professional Paper 1250, p. 683-687.

U.S. Senate Committeee on Interior and Insular Affairs, 1968, Mineral and water resources of Colorado: U.S. 90th Congress, $2 \mathrm{~d}$ session, Senate Document 115, $302 \mathrm{p}$. 



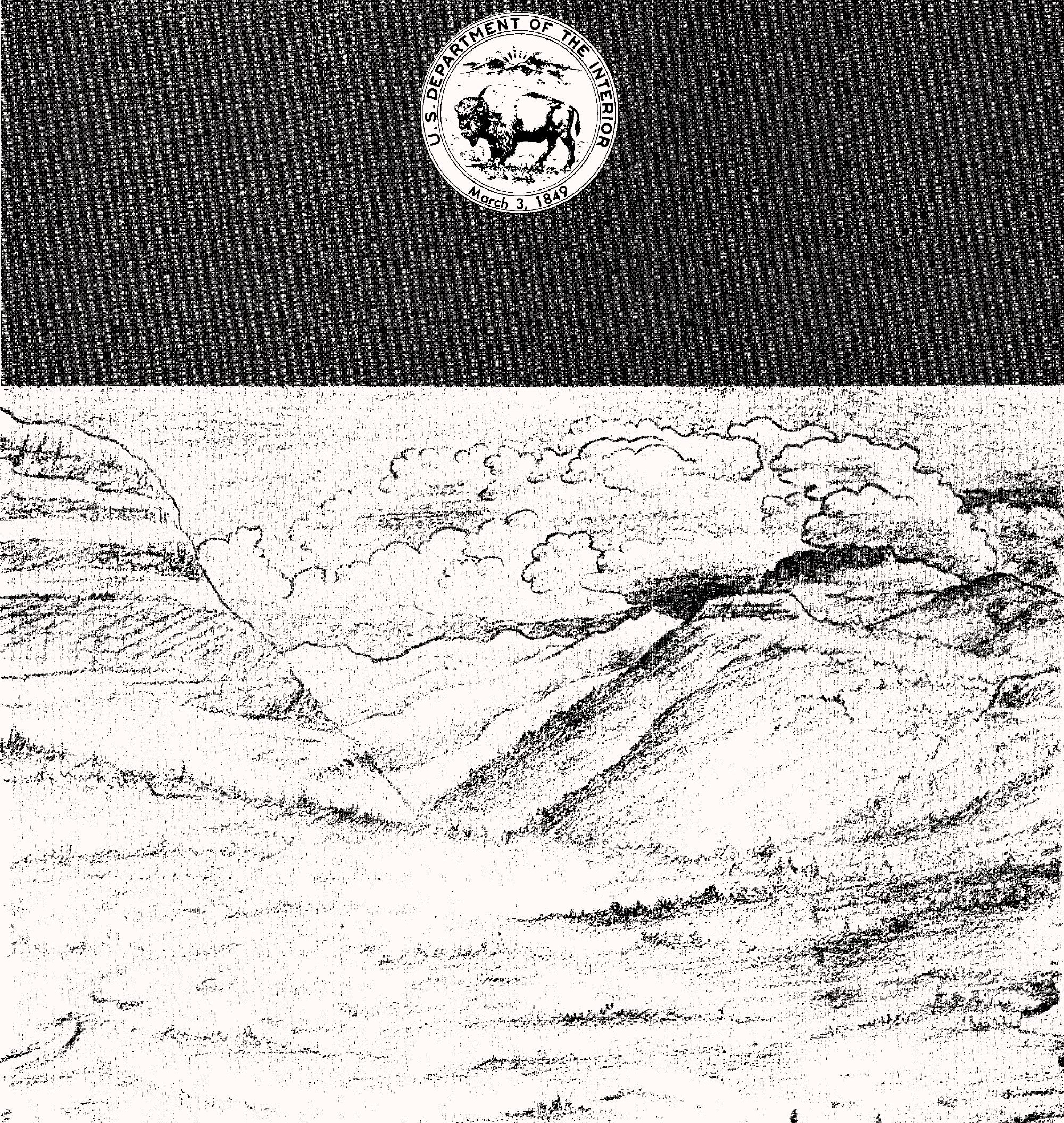